\title{
A Contribution towards the Life History of Parorchis acanthus Nicoll, a Trematode in the Herring Gull.
}

\author{
By \\ Marie V. Lebour, D.Sc., \\ Naturalist at the Plymouth Laboratory, \\ AND \\ Richard Elmhirst, F.L.S., \\ Superintendent of the Marine Biological Station, Millport.
}

With 1 Figure in the Text.

Parorchis acanthus is a Trematode described by Nicoll (1907) from the bursa Fabricii and rectum of the Herring Gull, Larus argentatus ; in 1906 he first described it as Zeugorchis acanthus. Originally found at St. Andrews, it is now known to be common at Millport and also occurs in gulls from the Northumberland coast, and probably is abundant elsewhere. Nicoll found it once in the Common Gull, Larus canus. In 1907 (Lebour, 1907) one of the present writers described a cercaria occurring in rediæ from Purpura lapillus. This was named Cercaria purpura sp. inq., and afterwards identified with young stages of Parorchis acanthus in the Herring Gull (Lebour, 1914). It was thus shown that the first host of this Trematode is Purpura lapillus and the final host the Herring Gull, but the intermediate host was unknown. Localities for the cercaria were Loch Ryan, Wigtownshire; Budle Bay, Fenham Flats and Cullercoats in Northumberland; Robin Hood's Bay in Yorkshire; and Millport. Adults occur at St. Andrews, Northumberland coast and Millport, as already stated.

The Cercaria appeared to be closely related to Echinostomum cercariæ, and it was suggested (Lebour, 1914) that the intermediate host would probably be some marine bivalve, as it is often so with Echinostomum (e.g. E. secundum in Mytilus edulis and Cardium edule, E. leptosomum in Scrobicularia tenuis). This suggestion now proves to be correct, and we are able to show that the intermediate host of Parorchis acanthus is Mytilus edulis or Cardium edule.

On August 13th, 1921, at the Millport Station some larval cercariæ were noticed by Elmhirst swimming in a small glass aquarium, which contained a collection of Purpura lapillus, Cardium edule and Mytilus edulis. These cercariæ, which swam actively by a strong side to side lash- 
ing of the tail, appearing to the naked eye rather like Chironomid larvæ, were identified as Cercaria purpurce. The Cardium and Mytilus were kept alive, and at the same time other specimens of Mytilus were put in another aquarium and some cercariæ from the infected Purpura added.

On September 4th, 1921, these Cardium and Mytilus from the first aquarium were carefully examined, with the result that the Cardium (one specimen only) contained two distinct species of Trematodes encysted in its tissues; the more abundant species, which occurred in the foot, was Echinostomum secundum, the other which occurred both in the foot and mantle, but not so abundantly, was undoubtedly Cercaria purpura. Two specimens of Mytilus also contained the Cercaria purpurce in the mantle, more abundantly than Cardium, but no Echinostomum. Parorchis acanthus is such a very distinct species that there is no mistaking it, and there seems no doubt at all that we have now found in Cardium edule and Mytilus edulis the intermediate hosts of Parorchis acanthus. The life history is this :-

First Host. Purpura lapillus.
Intermediate Host.

Cardium edule.

Mytilus edulis.
Final Host.

Larus argentatus.

Larus canus.

The Mytilus from the second aquarium were also examined, but were not infected, possibly because the cercariæ removed from the Purpura were not quite ready to enter their second stage.

The cysts differ from those of Echinostomum in their shape, one side being flattened and the other convex, the outer sheath being drawn out into a rim, giving the cyst the appearance of a hat (Fig. 1), not unlike the egg capsule of Littorina littorea. The outer sheath is very tough and thick, ca $0.012 \mathrm{~mm}$., and of a brownish colour. The cysts of Echinostomum being ordinarily rounded or oval-shaped, they are at once distinguished from these. The normal habitat for these cysts of Parorchis seems to be the mantle; and the flat side was, in most cases, lying nearest the shell.

Seen from above the cyst is roundish oval, measuring without the margin from $0 \cdot 24 \mathrm{~mm}$. to $0.28 \mathrm{~mm}$. long by $0.20 \mathrm{~mm}$. to $0.22 \mathrm{~mm}$. broad. The wall consists of two parts, the outer brownish tough sheath, to which is attached the flattened margin, and an inner perfectly transparent sheath, which is very thin walled. In this latter sheath lies the larva curled up (Fig. 2). Through the cyst wall can be seen the thick spines set on the body, the main excretory ducts leading to the excretory vesicle, the oral and ventral suckers and the pharynx. The worm when pressed out of the cyst is like the older free-swimming cercaria from Purpura, but 
without the tail, and also clearly resembles the young stages of Parorchis acanthus in the Herring Gull. There can be no doubt that we have here the same species. The suckers are slightly larger than in the tailed form : tailed form, oral sucker $0.06 \mathrm{~mm}$., ventral sucker $0.099 \mathrm{~mm}$.; encysted form, oral sucker $0.08 \mathrm{~mm}$., ventral sucker $0 \cdot 10-0 \cdot 14 \mathrm{~mm}$. In the small forms from the gull both suckers have grown and in the adult they are still larger, the ventral nearly twice as great as the oral.
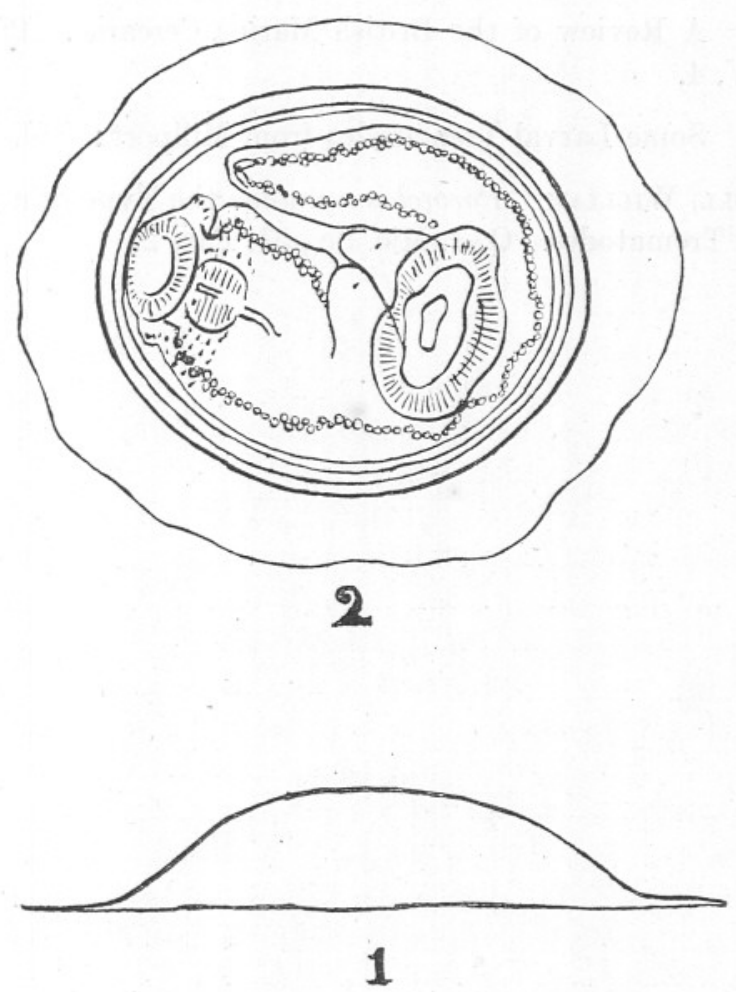

Fig. 1. Cyst in side view.

Fig. 2. Cyst from above with contained Trematode.

It is to be noted that no younger stages than the rediæ were ever seen in the Purpura, and this is interesting in the light of recent observations made on a species of Echinostomum (E. revolutum) by Johnson (1920), who finds that the miracidium develops into a mother redia, and this gives rise to the daughter rediæ. It is very probable that the same takes place in Parorchis, and that the rediæ so commonly found are the daughter rediæ developed from mother rediæ and that no sporocyst occurs. 


\section{LITERATURE.}

1920. Johnson, John C. The Life Cycle of Echinostomum revolutum (Froelich). University of California Publications, Vol. XIX No. 11.

1907. Lebour, M. V. On Three Mollusk-infesting Trematodes. Ann. and Mag. Nat. Hist., S. 7, Vol. XIX.

1912. — A Review of the British Marine Cercariæ. Parasitology, IV, 4.

1914. — Some Larval Trematodes from Millport: ibid. VII, 1.

1907. Nicold, William. Parorchis acanthus the Type of a new Genus of Trematodes. Q. J. Mic. Sc., 51, Part 2. 